\title{
Factors Affecting Laborers' Productivity in the Construction Companies
}

\author{
Phoebe Anne M. Banez, Chona Y. Co, Kristine M. Falconitin, Felipe E.Balaria, \\ Jennifer G. Fronda
}

\begin{abstract}
The purpose of this research paper is to determine factors affecting the productivity of laborers in construction companies in Nueva Ecija, Philippines. The researchers find this important especially to big construction industries, as it will able to guide them in hiring the best people for the job. The methodology used in this research is a descriptive-survey with questionnaire as the main instrument answered by both the laborers and their supervisors who served as respondents of this study. The study found out that the productivity of the laborers sometimes exceeds standards or expectations which implied that they have advanced knowledge in their work. Further, age and monthly compensation were the two main factors that affected their productivity which was an indication that mature laborers with higher monthly income were more productive employees.
\end{abstract}

Keywords - Business, construction companies, laborers, monthly income, productive employees.

\section{INTRODUCTION}

A prosperous construction project has countless essential components. One of those is the laborers. Laborers play a very significant role in the construction business from the onset of the task to its completion within a specified time; that is why their productivity should be observed. Productivity can be defined in many ways. In construction, productivity is usually taken to mean labor productivity; that is, units of work placed or produced per man-hour [1]. Laborers productivity determines the ability of the construction to meet its customers demand and financial objectives. A noncompliance workforce may put the construction company in jeopardy and will entail extra operational cost.

"Some factors affecting labor productivity or the performance of individual work roles include individual attitudinal, motivational and behavioral factors, individual rewards and payment systems [2]". Understanding critical factors that affect laborers productivity can help develop strategies that are easy and efficient way [3] to reduce inefficiencies and to effectively manage construction labor force. This will not only improve the project performance of construction companies but also make them more competitive.

Similarly, the workers' productivity affected the overall worth of the job and the task. The necessity for productivity was perhaps more important in the construction sector compared to any other sector. "It was necessary to implement, as far as possible, industry-wide principles of production throughout the construction process for managers to make accurate decisions given available information [4]". Though, it was known that careful adaptation would be required to implement the knowledge and experience gained in the manufacturing industry to the building construction industry [5] as cited in [6].

In the Philippines, the construction industry employs workers with different types of occupations, from licensed professionals and executives to unskilled workers. Traditionally the construction industry took a significant portion of employment for many countries all around the world. The authors in [7] "explored various factors affecting laborers productivity such as lack of materials, delay in the arrival of material, unclear instruction to laborers, laborers strikes, financial difficulties, higher absenteeism of laborers, no supervision method, supervisors absenteeism, lack of equipment and design change. However, some others factors to be considered is in the side of laborers like; poor health conditions, working without taking a holiday or rest day and drinking habits. These may consider major concerns for any construction and profitable business and should be addressed immediately if they want to have more chance of becoming successful [8]".

At present, construction projects are usually covered by a Memorandum of Agreement or Contract containing the details and description of the project including the payment schedule, cost, and timelines for the completion of the project both agreed by the contractor and the customer. In some cases, there are delays in the progress of the project due to lacking equipment's, availability of materials, incomplete legal requirements, poor quality, overhead and high cost of wages of laborers and weather condition. The 
costs of these interruptions may perhaps end in a severe loss of money for the contractor. Proper work planning and smart tools will enable work planners to identify, quantify, reduce, and eliminate the possible causes of delays in the project, hence improving the productivity and will stay on the agreed budget. Thus, this study was conceptualized. It determined the productivity of the laborers and factors affecting the productivity so that contractors and owners can effectively plan the operations and finished projects on time to reduce unnecessary costs because of delay. This action is beneficial to contractors and owners since it can continuously help them in developing and improving their problem solving and critical thinking skills [9] which are needed for them to thrive in this kind of business.

\section{METHODOLOGY}

This study utilized the descriptive-correlational research design to determine the factors affecting the laborers' productivity in the three selected construction companies in
Nueva Ecija, Philippines. According to [10], as cited in [11], "Correlational research is employed to test the degree of relationship between two variables".

The main instrument used in this study was a questionnaire composed of two parts. Part 1 outlined the respondents' profile in terms of age, civil status and educational attainment and Part 2 consisted of a checklist designed to assess the factors that affect laborer's productivity towards their work. Frequency, percentage, weighted mean, Spearman's rho, and Pearson's $r$ were used in analyzing the gathered data.

Random sampling was used to choose 70 respondents of this study.

The respondents were asked to choose one rating opposite each description on a scale of 1 to 5 (see Table 1), where five (5) is the highest point and one (1) as the lowest.

Table 1. Scale for the Productivity of the Laborers

\begin{tabular}{c|c|l}
\hline Scale & Rating & \multicolumn{1}{c}{ Description } \\
\hline 5 & $\begin{array}{c}\text { Excellent/ } \\
\text { Outstanding }\end{array}$ & The productivity exceeds standards or expectations / Has mastered the skills and can train others \\
\hline 4 & Above Average & The productivity Sometimes exceeds standards or expectations / Has advanced knowledge \\
\hline 3 & Satisfactory & $\begin{array}{l}\text { The productivity Meets standards or expectations / Can perform effectively without the } \\
\text { supervision }\end{array}$ \\
\hline 2 & Fair/Must Improve & $\begin{array}{l}\text { The productivity Sometimes fall below standards or expectations / Can perform with close } \\
\text { supervision }\end{array}$ \\
\hline 1 & Poor/Unsatisfactory & The productivity Often fall below standards or expectations / Has basic knowledge \\
\hline
\end{tabular}

\section{RESULTS AND DISCUSSION}

\section{Profile of the Respondents}

The average age of the laborers in the three (3) constructions companies ranges from 20 years to 39 years old or basically at the middle age. This indicates that construction companies prefer to hire young laborers. As to the laborers' educational attainment, most of them are high school levels or high school graduates. Moreover, most of them are married with a monthly salary amounting to more or less Php10,000.00 per month and with less than ten years of experience in the construction industry.

2. The productivity of the Laborers as described by them and their Supervisors
Table 2. Productivity of the Laborers

\begin{tabular}{l|c|c|r|l}
\hline & Laborers & Supervisors & & \\
\hline PRODUCTIVTY & WM & WM & Average & VD \\
\hline $\begin{array}{l}\text { 1. Knowledge of } \\
\text { the job }\end{array}$ & 4.01 & 3.77 & 3.89 & AA \\
\hline $\begin{array}{l}\text { 2. Quality, } \\
\text { Neatness, } \\
\text { Accuracy }\end{array}$ & 3.86 & 3.79 & 3.83 & AA \\
\hline $\begin{array}{l}\text { 3.Expediting work } \\
\text { under pressure }\end{array}$ & 3.57 & 3.56 & 3.57 & AA \\
\hline $\begin{array}{l}\text { 4.Interpersonal } \\
\text { Relations }\end{array}$ & 3.94 & 3.79 & 3.87 & AA \\
\hline $\begin{array}{l}\text { 5.Initiative and } \\
\text { interest }\end{array}$ & 3.91 & 3.83 & 3.87 & AA \\
\hline $\begin{array}{l}\text { 6.Exercising } \\
\text { judgment }\end{array}$ & 3.67 & 3.61 & 3.64 & AA \\
\hline $\begin{array}{l}\text { 7.Ability to accept } \\
\text { innovations and } \\
\text { changes }\end{array}$ & 3.99 & 3.87 & & \\
\hline
\end{tabular}




\begin{tabular}{l|c|c|r|c}
\hline $\begin{array}{l}\text { 8.Communication: } \\
\text { Verbal and written }\end{array}$ & 3.44 & 3.41 & 3.43 & AA \\
\hline $\begin{array}{l}\text { 9.Observance of } \\
\text { company' rules } \\
\text { and regulations }\end{array}$ & 3.81 & 3.87 & 3.84 & AA \\
\hline $\begin{array}{l}\text { 10. Customer and } \\
\text { co-workers } \\
\text { relations }\end{array}$ & 3.69 & 3.67 & 3.68 & AA \\
\hline 11. Dependability & 3.74 & 3.7 & 3.72 & AA \\
\hline 12. Attendance & 4.31 & 3.99 & 4.15 & AA \\
\hline OWM & 3.83 & 3.74 & 3.79 & AA \\
\hline
\end{tabular}

Productivity, as described by the laborers and supervisors, resulted in an overall weighted mean of 3.79 with a verbal interpretation of above average. This means that the productivity of the laborers sometimes exceeds the standards or expectations. They particularly exceed expectations with their attendance and their ability to accept innovations and changes. This further implies that the respondent-laborers are punctual and are responsible and open-minded, flexible and adaptive individuals.

3. Significant Difference in the Responses of the Two Groups regarding the Productivity of the Laborers

Table 3. Comparison of the Responses as to the Productivity of the Laborers

\begin{tabular}{l|c|c}
\hline Productivity of the Laborers & Supervisors & Laborers \\
\hline Mean & 3.74 & 3.83 \\
\hline Variance & 0.0245 & 0.0531 \\
\hline t Stat & \multicolumn{2}{|c}{$-1.140 \mathrm{Ns}$} \\
\hline t Critical two-tail & \multicolumn{2}{|c}{2.074} \\
\hline
\end{tabular}

Ns = no significant difference

The null hypothesis of no significant difference in the responses of the two groups of respondents is accepted since the t-Stat is less than t Critical two-tail. This result implies that the two groups of respondents have similar views regarding the productivity of the laborers.

4. Significant Relationship between the Profile of the Laborers and their Productivity

Table 4. Relationship between the Profile and the Productivity of the Laborers

\begin{tabular}{l|r|l|l}
\hline & \multicolumn{3}{|c}{ PRODUCTIVTY } \\
\hline & $\begin{array}{l}\text { lorrelat } \\
\text { ion } \\
\text { value }\end{array}$ & $\begin{array}{l}\boldsymbol{p} \text { - } \\
\text { value }\end{array}$ & Interpretation \\
\hline Age & $.306^{* *}$ & .010 & $\begin{array}{l}\text { Significant } \\
\text { relationship }\end{array}$ \\
\hline Civil Status & .230 & .055 & No significant \\
\hline
\end{tabular}

Age and monthly income are significantly related to productivity. This means that those mature laborers with higher monthly income are more productive employees of the business.

\section{CONCLUSION AND RECOMMENDATIONS}

Based on the result and analysis of the given data, the researchers concluded that: The age of laborers in the construction business is range from 20 to 39 years of age. Most of them reached high school level and high school graduate, and more than $70 \%$ of them are married. The majority had less than ten years in construction work experience. The laborers' self-assessment and their supervisors' as sessment of 3.83 and 3.74, respectively, both fell under the Above Average rating. Hence, there is no significant difference in the rating of the two groups of respondents regarding the productivity of the laborers. Further, age and monthly income are the major factors related to the productivity of the laborers in the construction business.

It is recommended that in hiring laborers, the owner of the construction business must take into consideration the age and salary scale to be given to them. Also, a periodic assessment both by the laborer and his superior must be conducted during the construction period to test their productivity and ensure the quality of work.

\section{REFERENCES}

[1] David W. Halligan, Laura A. Demsetz, James D. Brown, Clark B. Pace.Action-response model and loss of productivity in construction. Journal of Construction Engineering and Management, ASCE, 120 (1) (1994), pp. 47-64

[2] Manufacturing in Britain: A Survey of Factors Affecting Growth \& Performance, ISR/Google Books, revised 3rd edition. 2003, page 58. ISBN 978-0906321-30-0 [1] 
[3] Subia, G.S. (2018).Comprehensible Technique in Solving Consecutive Number Problems in Algebra. Journal of Applied Mathematics and Physics, 6,447457. https://doi.org/10.4236/jamp.2018.63041

[4] Subia, Gener S.(2018). Think Like My Teacher (TLMT): A New Method in Assessing Millennial Learners. International Journal of Arts Humanities and Social Sciences.Volume 3 Issue 1 || January 2018. www.ijahss.com

[5] Alarcon, L. F Borcherding, J. D., and. (1991). "Quantitative effects on construction productivity." The Construction Lawyer, American Bar Association, 11(1), 35-48.

[6] Mahesh Madan Gundecha (2012). Study of factors affecting labor productivity at a building construction project in the USA: web survey. Research Paper. North Dakota State University Of Agriculture and Applied Science

[7] Soekiman, A., et.al.(2011). Factors Relating to Labor Productivity Affecting the Project Schedule Performance in Indonesia.December 2011Procedia Engineering 14:865-873.DOI: 10.1016/j.proeng.2011.07.110

[8] Subia, Gener S., Salangsang, Lily G. and Medrano, Hernina B.(2018). Attitude and performance in mathematics I of bachelor of elementary education students: A correlational analysis. American Scientific Research Journal for Engineering, Technology, and Sciences (ASRJETS) (2018) Volume 39, No 1, pp 206-213

[9] Subia, G. , Amaranto, J. , Amaranto, J. , Bustamante, J. and Damaso, I. (2019) Chess and Mathematics Performance of College Players: An Exploratory Analysis. Open Access Library Journal, 6, 1-7. doi: 10.4236/oalib.1105195.

[10] Patten, M.L. (2002) Understanding Research Methods. Pyrczak Publishing, U.S.A.

[11] Subia, G.S., Florencondia, N.T., Trajano, Mercedes G.,Gutierrez, M.P, \& Zabala, B.A.(2018). Factors Associated with the Research Paper Writing Capabilities of Engineering Management and Vocational Technological Education Freshman Students. International Journal for Research \& Development in Technology. Volume-9,Issue-3 (Mar18).ISSN (O) :- 2349-3585 